\title{
The Influence of Lifestyle and Financial Literacy on Saving Behavior for Undergraduate Students in Indonesia
}

\author{
Rindah F. Suryawati ${ }^{1}$, Afriliany Dian Oetari ${ }^{2}$ \\ \{rindah.suryawati@apps.ipb.ac.id ${ }^{1}$, afriliany_dianoetari@apps.ipb.ac.id² \\ Department of Management, FEM - IPB University, Kampus Dramaga, Bogor 16680, Indonesia ${ }^{1,2}$
}

\begin{abstract}
Saving is one way to increase the country's gross domestic product through a third- party fund (DPK). In 2019, the GDP saving ratio is 30.78 percent. Undergraduate students, who are Z generation are known as "live for today". They are digital natives and their lifestyle is consequently being dynamic along the time. This study aims to analyze the influence of lifestyle and financial literacy on the saving behavior of undergraduate students in Indonesia. Questionnaires were distributed to 593 students in 34 provinces of Indonesia and were analyzed using multiple linear regression. The results of the data analysis show that lifestyle and financial literacy has significant impact on student saving behavior. The fulfilleds lifestyle, and financial attitude shows a positive attitude on saving behavior. This study provides additional evidence of the effect of lifestyle and financial literacy on saving behavior from an emerging country.
\end{abstract}

Keywords: Financial Literacy, Lifestyle, Saving Behavior, Undergraduate Students.

\section{Introduction}

Saving is one of the future investments that very important. Saving is one way to increase the country's Gross Domestic Product through Third Party Funds (DPK). The saving ratio of Indonesians is still lower than in many countries in Southeast Asia. In 2019, the Indonesian people could only contribute through the savings to GDP ratio of 30.78 percent. This is considered still quite low compared to neighboring countries, the Philippines.

Savings are also closely related to financial knowledge. One way to increase the level of savings can be done by encouraging desired financial behavior and increasing financial knowledge ${ }^{[18]}$. Financial literacy as knowledge and understanding of financial concepts and risks, 
along with the skills, motivation, and confidence to apply their knowledge and understanding to make financial decisions effective, improve the financial well-being of individuals and communities, and participate in the economic field ${ }^{[14]}$.

The National Financial Literacy Survey (SNLK) conducted by the Financial Services Authority (OJK) in 2019 gives the result that Indonesia's financial literacy index reached 38.03 percent $^{[15]}$. This gives an overview of the financial literacy conditions of the Indonesian people, it means that in every 100 residents only about 38 people have a good level of financial literacy. According to the 2013 Financial Services Authority (OJK) survey, the level of financial literacy of the Indonesian population is divided into four parts, namely well literate, sufficient literate, less literate, and not literate ${ }^{[16]}$. The comparison between Indonesia's financial literacy in 2013, 2016, and 2019 is given in Fig. 1.

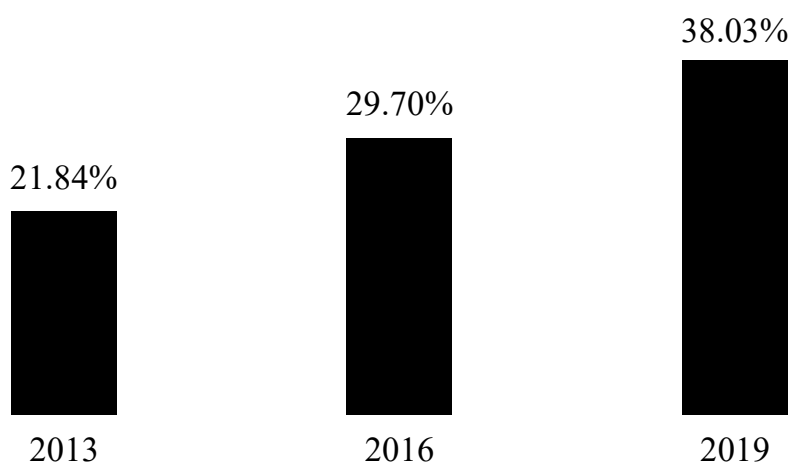

Fig. 1 Categories of Indonesian Financial Literacy Levels at the survey of OJK 2013

Source: ojk.go.id

The phenomenon of the industrial revolution 4.0 will increase consumer desire to shop. It is because technology has become easier ${ }^{[10]}$. The technology that makes shopping easy is online shopping. Young adults are those who are in a transition period where they begin to stop under parental supervision and begin to regulate their own lives, include take many decisions in finances. Based on a survey, the $\mathrm{Z}$ generation is also known as the generation that prioritizes life security, a competitive generation, has an independent spirit, can do various things at one time (multitasking), have an entrepreneurial spirit ${ }^{[4]}$. As a result, the lifestyle (lifestyle) of each generation will change with time. Lifestyle factors will also affect how a person behaves in managing money. The survey conducted by SRI (Stanford Research Institute) 
that the VALS2TM segmentation (Values, Attitude, and Lifestyle) divides adults in the United States into eight groups, namely actualizers, fulfilleds, achievers, experiencers, believers, strivers, makers, and strugglers ${ }^{[8]}$. According to data published by RistekDikti, in the 2018/2019 academic year, Indonesia had 8423280 students. The number of students is around 3.178 percent of the total population in Indonesia ${ }^{[17]}$.

Based on this background, the researcher was interested in research entitled "The Effect of Lifestyle and Financial Literacy on Saving Behavior for undergraduate Students in Indonesian". The purpose of this study are (1) Analyzing the lifestyle and financial literacy of undergraduate students in Indonesian, (2) Analyzing the relationship of lifestyle, financial literacy, and saving behavior of undergraduate students in Indonesian, (3) Analyzing the influence of lifestyle and financial literacy on saving behavior of undergraduate students in Indonesian, (4) Analyzing the influence of the type of lifestyle and financial literacy's component on saving behavior. This research focuses on Indonesia's active undergraduate students who are registered at the Ministry of Research, Technology, and Higher Education based on provinces in Indonesia. It is because students are one of the priority targets for financial education. In the lifestyle variable, the study only focuses on the group of people who are achievers, strivers, fulfilled, believers, experiences, and makers. In the financial literacy variable, indicators are based on planning, attitudes, and financial knowledge. This study analyzes the influence that occurs between lifestyle and level of financial literacy on student saving behavior.

\section{Hypothesis Development}

H1: Lifestyle has a significant effect on saving behavior

Students with low spending patterns do not have good financial management behavior ${ }^{[19]}$. It means that someone with a certain lifestyle will influence how they will manage their finances, including how they save their money. The factors that influence a person's saving behavior with qualitative research states that respondents with very large influence and have a luxurious lifestyle should tend to have a harder effort to manage finances ${ }^{[1]}$. On the other hand, respondents who choose friends wisely and manage their interactions only for close friends tend to be able to manage their finances well, including how to 
save their money. Therefore, this study has a hypothesis that lifestyle has a significant effect on saving behavior. If someone can adjust their lifestyle, they will be able to manage their money including save the money for future needs.

H2: Financial Literacy has a significant effect on saving behavior Based on a survey conducted by Washington State residents, financial literacy has a positive effect on investment and long-term saving behavior ${ }^{[9]}$. Financial literacy also plays an important role in influencing a person's choice of having a portfolio ${ }^{[12]}$. Individuals with a high level of actual financial knowledge are more likely to have savings with odds ratios exceeding 6.5. Financial knowledge will influence individual preferences, such as avoiding risk. The study stated if a person has a lower financial literacy, they will avoid risk. Individuals with low financial literacy will become individuals who do not like a risk because the level of financial literacy will determine individuals to choose investment products and take risks from investment products used, especially investment products in the long term $^{[2]}$. Perceived financial knowledge is a strong indicator of influencing saving behavior ${ }^{[7]}$. Therefore, this study has a hypothesis that financial literacy will have a significant effect and influence a person's saving behavior. Thus, the higher financial literacy, they likely tend to have a routine saving behavior and a high percentage of savings.

\section{Method}

This is a survey questionnaire research. The subject of this research is active students in Indonesia based on where they are studying and divided by province. The students are at level 2 (semester 4), level 3 (semester 6), and level 4 (semester 8). Data processing and analysis methods used are descriptive analysis and multiple linear regression analysis. The tools used to analyze are Microsoft Excel 2019, and IBM SPSS 23. The financial literacy questionnaire consists of 22 questions, adapted from the OECD / INFE Questionnaire for Measuring Financial Literacy and Financial Inclusion in 2018 ${ }^{[13]}$, the lifestyle questionnaire consisted of 25 questions, adapted from the VALS2TM segmentation based on a survey conducted by the Stanford Research Institute (SRI). The questionnaire consisted of achievers, 
strivers, fulfillers, believers, experiences, and the maker's lifestyle styles ${ }^{[8]}$. The savings behavior questionnaire consists of 10 questions, adapted from several journals. The journal that became a reference for researchers in making a saving behavior questionnaire were A Study of Financial Awareness Among Youth ${ }^{[11]}$, Saving Behavior and Financial Problems Among College Students ${ }^{[19]}$, The Saving and Spending Habits of Young People ${ }^{[5]}$, Determinants of Saving Behavior and Financial Problems Among Employees in Malaysia ${ }^{[3]}$.

\section{Samples}

The number of samples is determined based on the Slovin formula with a standard error is 5 percent. The samples amounted to 593 students throughout Indonesia with a sampling technique is cluster sampling. The number of respondents presented in Table 1 .

Table 1 The number of respondents divided by province

\begin{tabular}{ccccc}
\hline No & Provinces & $\begin{array}{c}\text { Undergraduate } \\
\text { Students }\end{array}$ & $\begin{array}{c}\text { Percentage } \\
\mathbf{( \% )}\end{array}$ & Samples \\
\hline 1 & Aceh & 159023 & $1.888 \%$ & 12 \\
2 & North Sumatera & 485458 & $5.763 \%$ & 23 \\
3 & West Sumatera & 214870 & $2.551 \%$ & 12 \\
4 & Riau & 160107 & $1.901 \%$ & 12 \\
5 & Riau Island & 52740 & $0.626 \%$ & 12 \\
6 & Jambi & 80478 & $0.955 \%$ & 12 \\
7 & South Sumatera & 164584 & $1.954 \%$ & 12 \\
8 & Bangka Belitung & 14875 & $0.177 \%$ & 12 \\
9 & Bengkulu & 58050 & $0.689 \%$ & 12 \\
10 & Lampung & 140046 & $1.663 \%$ & 12 \\
11 & DKI Jakarta & 1565529 & $18.586 \%$ & 74 \\
12 & West Java & 1010963 & $12.002 \%$ & 48 \\
13 & Banten & 316801 & $3.761 \%$ & 15 \\
14 & Central Java & 682686 & $8.105 \%$ & 32 \\
15 & Yogyakarta & 459160 & $5.451 \%$ & 22 \\
16 & East Java & 1003312 & $11.911 \%$ & 48 \\
17 & West Kalimantan & 109313 & $1.298 \%$ & 12 \\
18 & Central Kalimantan & 39098 & $0.464 \%$ & 12 \\
19 & South Kalimantan & 108490 & $1.288 \%$ & 12 \\
20 & East Kalimantan & 111032 & $1.318 \%$ & 12 \\
21 & North Kalimantan & 12860 & $0.153 \%$ & 12 \\
\hline
\end{tabular}


Table 1 The number of respondents divided by province

\begin{tabular}{ccccc}
\hline No & Provinces & $\begin{array}{c}\text { Undergraduate } \\
\text { Students }\end{array}$ & $\begin{array}{c}\text { Percentage } \\
\mathbf{( \% )}\end{array}$ & Samples \\
\hline 22 & North Sulawesi & 112427 & $1.335 \%$ & 12 \\
23 & Gorontalo & 54526 & $0.647 \%$ & 12 \\
24 & Central Sulawesi & 107116 & $1.272 \%$ & 12 \\
25 & South Sulawesi & 405244 & $4.811 \%$ & 19 \\
26 & West Sulawesi & 26886 & $0.319 \%$ & 12 \\
27 & Southeast Sulawesi & 123574 & $1.467 \%$ & 12 \\
28 & Bali & 160314 & $1.903 \%$ & 12 \\
29 & West Nusa Tenggara & 106863 & $1.269 \%$ & 12 \\
30 & East Nusa Tenggara & 135404 & $1.607 \%$ & 12 \\
31 & Maluku & 53195 & $0.632 \%$ & 12 \\
32 & North Maluku & 47862 & $0.568 \%$ & 12 \\
33 & Papua & 95838 & $1.138 \%$ & 12 \\
34 & West Papua & 44556 & $0.529 \%$ & 12 \\
TOTAL & $\mathbf{8 ~ 4 2 3 ~ 2 8 0}$ & $100 \%$ & 593 & \\
\hline
\end{tabular}

Sources: Data processed (2020)

Processing and Analysis of Data Validity and Reliability Test

A valid instrument means that the instrument can be used to measure what should be measured ${ }^{[20]}$. A reliable instrument is an instrument when used several times to measure the same object, will produce the same data ${ }^{[20]}$. Reliability measures how the results can be trusted in several times with the same subject will give relatively the same results. 


\section{Descriptive Analysis}

Lifestyle index scores are calculated per lifestyle dimension (achievers, strivers, fulfillers, believers, experience, and makers). Students are categorized as having one type of lifestyle based on the maximum value obtained from the index score per type of lifestyle. The category for the level of student financial literacy refers to the 4 categories of financial literacy implemented by the OJK (2013)[16], namely well literate, sufficient literate, less literate, and not literate.

Multiple Linear Regression Analysis

Regression analysis is a data analysis technique in statistics that measures the strength of the relationship between two or more variables, also shows the direction of the relationship between the dependent variable and the independent variable ${ }^{[6]}$. The dependent variable is assumed to be random, which means that it has a probabilistic distribution. The independent variable is assumed to have a fixed value. Multiple linear regression tests to analyze the influence of lifestyle, and financial literacy on the saving behavior of Indonesian students. The variables measured were the variables of lifestyle, financial literacy, and saving behavior. Before the multiple linear regression analysis, the data need a classic assumption test consist of a normality test, multicollinearity test, and heteroskedasticity test.

The formula of the multiple linear regression model for the regression test is as follows:

$$
\mathrm{Y}=\alpha+\beta_{1} \mathrm{X}_{1}+\beta_{2} \mathrm{X}_{2}+\beta_{3} \mathrm{X}_{3}+\beta_{4} \mathrm{X}_{4}+\beta_{5} \mathrm{X}_{5}+\beta_{6} \mathrm{X}_{6}+\beta_{7} \mathrm{X}_{7}+\beta_{8} \mathrm{X}_{8}+
$$

$$
\begin{aligned}
& \text { Information: } \\
& \mathrm{Y}=\text { Saving Behavior } \\
& \alpha=\text { Constanta } \\
& \beta \quad=\text { Regression Coefficient } \\
& \mathrm{X}_{1}=\text { Achievers } \\
& \mathrm{X}_{2}=\text { Strivers } \\
& \mathrm{X}_{3}=\text { Fulfilleds } \\
& \mathrm{X}_{4}=\text { Believers } \\
& \mathrm{X}_{5}=\text { Experiencers } \\
& \mathrm{X}_{6}=\text { Makers }
\end{aligned}
$$




$$
\begin{array}{ll}
\mathrm{X}_{7} & =\text { Financial Planning } \\
\mathrm{X}_{8} & =\text { Financial Attitude } \\
\mathrm{X}_{9} & =\text { Financial Knowledge } \\
\varepsilon & =\text { Standard Error }
\end{array}
$$

\begin{tabular}{|c|c|c|c|}
\hline Variabel & Definition & Indicator & Source \\
\hline $\begin{array}{l}\text { Undergraduate } \\
\text { Students }\end{array}$ & $\begin{array}{l}\text { A person who is } \\
\text { actively studying at } \\
\text { the undergraduate } \\
\text { level in all } \\
\text { universities in } \\
\text { Indonesia. }\end{array}$ & & $\begin{array}{l}\text { Sabri at al. } \\
(2010)^{[19]}\end{array}$ \\
\hline Lifestyle & $\begin{array}{l}\text { The patterns that } \\
\text { describe how } \\
\text { students live, spend, } \\
\text { or use their money } \\
\text { and time. }\end{array}$ & $\begin{array}{ll}\text { 1. } & \text { Fulfilleds } \\
\text { 2. } & \text { Believers } \\
\text { 3. } & \text { Achievers } \\
\text { 4. } & \text { Strivers } \\
\text { 5. } & \text { Experiencers } \\
\text { 6. } & \text { Makers }\end{array}$ & $\begin{array}{l}\text { Michman et } \\
\text { al. }(2003)^{[8]}\end{array}$ \\
\hline $\begin{array}{l}\text { Financial } \\
\text { Literacy }\end{array}$ & $\begin{array}{l}\text { Student's knowledge } \\
\text { of financial concepts } \\
\text { and principles in } \\
\text { managing their } \\
\text { finances. }\end{array}$ & $\begin{array}{ll}\text { 1. Financial Planning } \\
\text { and Management } \\
\text { 2. Financial } \\
\text { Attitudes and } \\
\text { Behavior } \\
\text { 3. Financial } \\
\text { Knowledge } \\
\end{array}$ & $\begin{array}{l}\text { OECD/INFE } \\
(2018)^{[13]}\end{array}$ \\
\hline $\begin{array}{l}\text { Saving } \\
\text { Behavior }\end{array}$ & $\begin{array}{l}\text { The behavior of } \\
\text { setting proportionally } \\
\text { of income for a } \\
\text { specific purpose in the } \\
\text { present or the future. }\end{array}$ & & $\begin{array}{l}\text { Bamford } \\
(2017)^{[1]}\end{array}$ \\
\hline
\end{tabular}

Operational Definition

Table 2 Operational Definition

Source: Data processed (2020)

\section{Result and Discussion}

\section{Validity and Reliability Test}

The validity criteria is significance $<0.05$ and the reliability criterion is Cronbach's Alpha value $>0.60$. All questions in the lifestyle questionnaire, financial literacy, and saving behavior have a significance value $<0.05$. All questions in the questionnaire have met 
the criteria of validity and reliability, so the research instruments are declared valid and reliable.

Table 3 The result of validity and reliability test

\begin{tabular}{lcc}
\hline Indicator & $\begin{array}{c}\text { Valid } \\
\text { Question }\end{array}$ & $\begin{array}{c}\text { Cronbach's } \\
\text { alpha value }\end{array}$ \\
\hline Achiever & 6 & 0.615 \\
Strivers & 3 & 0.601 \\
Fulfilleds & 7 & 0.740 \\
Believers & 3 & 0.612 \\
Experience & 3 & 0.606 \\
Makers & 3 & 0.622 \\
Financial Planning & 6 & 0.714 \\
Financial Attitude & 9 & 0.612 \\
Financial Knowledge & 7 & 0.609 \\
Saving Behavior & 10 & 0,638 \\
\hline
\end{tabular}

Source: Data processed (2020)

Classic Assumption Test

\section{Normality Test}

The normality test is performed for the independent and dependent variables in a regression model that is normally or not normally distributed. If a variable is not normally distributed, the statistical test results will decrease. In the normality test, the results show that the data in this study are normally distributed. The results of the normality test are presented in Figure 3. 


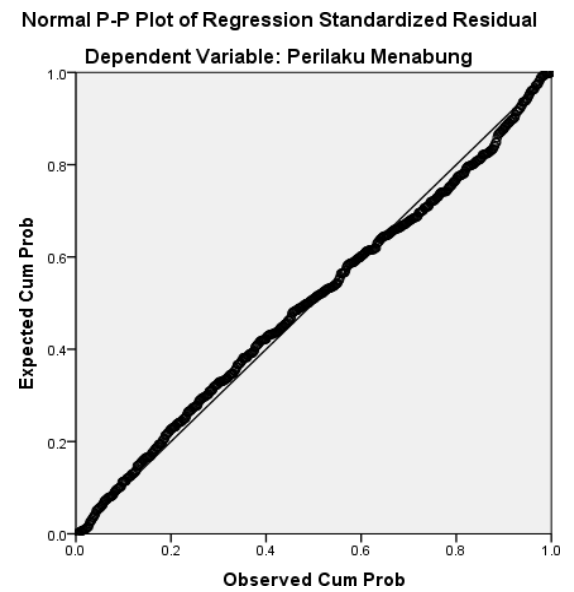

Fig. 3 Normality Test

Source: Data processed (2020)

\section{Multicollinearity test}

The multicollinearity test aims to determine the correlation between independent variables or independent variables. To perform the multicollinearity test, it is done by looking at the tolerance and VIF values in the coefficient table. If the tolerance value is $>0.100$ and VIF $<10.00$, then the data is declared to have no multicollinearity symptoms. In the multicollinearity test, the results showed that there were no symptoms of multicollinearity. The multicollinearity test results are presented in Table 4.

Table 4 Multicollinearity test

\begin{tabular}{lcc}
\hline Independent Variable & Tolerance & VIF \\
\hline Achievers & 0.630 & 1.588 \\
Strivers & 0.884 & 1.131 \\
Fulfilleds & 0.582 & 1.717 \\
Believers & 0.823 & 1.215 \\
Experiencers & 0.820 & 1.220 \\
Makers & 0.827 & 1.209 \\
Financial Planning & 0.849 & 1.179 \\
Financial Attitude & 0.695 & 1.440 \\
Financial Knowledge & 0.981 & 1.019 \\
& & \\
\hline
\end{tabular}

Source: Data processed (2020) 


\section{Heteroscedasticity Test}

The heteroscedasticity test aims to test whether in a regression model there is variant discomfort from the residuals in one observation to another. The heteroscedasticity test is done by looking at the scatterplot graph. If there is no certain pattern on the graph, it can be concluded that there are no symptoms of heteroscedasticity. In the heteroscedasticity test, the results showed that there were no symptoms of heteroscedasticity. The results of the heteroscedasticity test are presented in Figure 4.

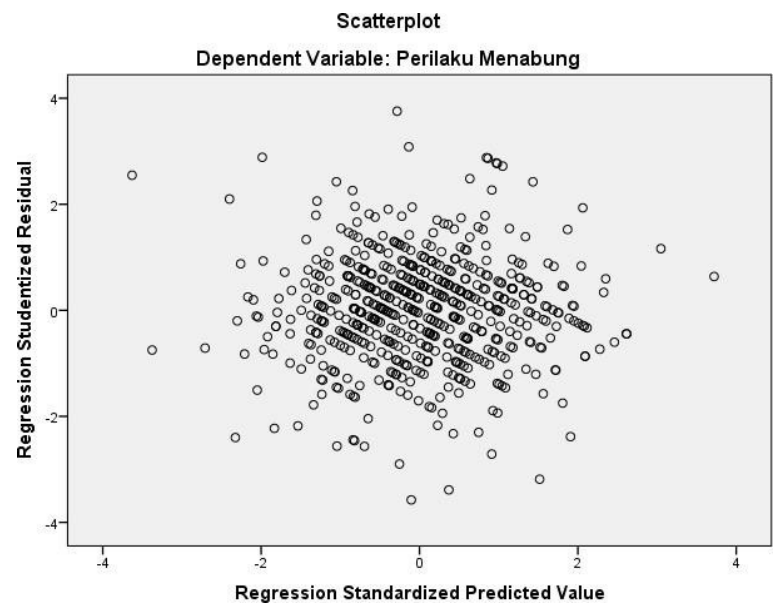

Fig. 4 Heteroscedasticity Test

Source: Data processed (2020)

\section{Undergraduate Students Characteristics}

Respondents in this study were 593 active students throughout Indonesia who were in semesters 4,6 , and 8 . Characteristics of respondents included gender, semester level (academic year), region, income, and expenditure. 
Table 5 Undergraduate Students Characteristics

\begin{tabular}{|c|c|c|}
\hline Characteristics & Information & $\begin{array}{l}\text { Number } \\
\text { of people }\end{array}$ \\
\hline \multirow[t]{2}{*}{ Gender } & Man & 181 \\
\hline & Woman & 412 \\
\hline \multirow[t]{3}{*}{ Academic Year } & 2016 & 255 \\
\hline & 2017 & 171 \\
\hline & 2018 & 167 \\
\hline \multirow[t]{31}{*}{ Area } & Aceh & 12 \\
\hline & North Sumatera & 23 \\
\hline & West Sumatera & 12 \\
\hline & Riau & 12 \\
\hline & Riau Island & 12 \\
\hline & Jambi & 12 \\
\hline & South Sumatera & 12 \\
\hline & Bangka Belitung & 12 \\
\hline & Bengkulu & 12 \\
\hline & Lampung & 12 \\
\hline & DKI Jakarta & 74 \\
\hline & West Java & 48 \\
\hline & Banten & 15 \\
\hline & Central Java & 32 \\
\hline & Yogyakarta & 22 \\
\hline & East Java & 48 \\
\hline & West Kalimantan & 12 \\
\hline & Central Kalimantan & 12 \\
\hline & South Kalimantan & 12 \\
\hline & East Kalimantan & 12 \\
\hline & North Kalimantan & 12 \\
\hline & North Sulawesi & 12 \\
\hline & Gorontalo & 12 \\
\hline & Central Sulawesi & 12 \\
\hline & South Sulawesi & 19 \\
\hline & West Sulawesi & 12 \\
\hline & Southeast Sulawesi & 12 \\
\hline & Bali & 12 \\
\hline & West Nusa Tenggara & 12 \\
\hline & East Nusa Tenggara & 12 \\
\hline & Maluku & 12 \\
\hline
\end{tabular}


Table 5 Undergraduate Students Characteristics

\begin{tabular}{lcc}
\hline Characteristics & Information & $\begin{array}{c}\text { Number of } \\
\text { people }\end{array}$ \\
\hline & North Maluku & 12 \\
Papua & 12 \\
Income & West Papua & 12 \\
& Rp1.000.000 & 292 \\
& Rp1.000.001 - Rp1.500.000 & 177 \\
& Rp2.500.001 - Rp2.000.000 & 80 \\
Expense & Rp3.000.000 - Rp5.000.000 & 23 \\
& $>$ Rp5.000.000 & 11 \\
& $\leq \mathrm{Rp} 1.000 .000$ & 10 \\
& $\mathrm{Rp} 1.000 .001-\mathrm{Rp} 1.500 .000$ & 327 \\
$\mathrm{Rp} 1.500 .001-\mathrm{Rp} 2.000 .000$ & 497 \\
$\mathrm{Rp} 2.000 .000-\mathrm{Rp} 3.000 .000$ & 21 \\
$\mathrm{Rp} 3.000 .000-\mathrm{Rp} 5.000 .000$ & 5 \\
& $>\mathrm{Rp} 5.000 .000$ & 3 \\
\hline
\end{tabular}

Source: Data processed (2020)

Based on Table 5, the majority of respondents were female students as 412 people $(69.48 \%)$ and the male were 181 people $(30.52 \%)$. The distribution of respondents with the highest number is DKI Jakarta as 74 people. The majority of respondents were students with a 2016 academic year or in semester 8 with 255 people (43\%), 2017 academic year or in semester 6 with 171 (28.84\%), and 2018 academic year or in the semester 4 with a total of 167 people $(28.16 \%)$. In terms of income characteristics, the majority of student income is $\leq$ Rp1,000,000 with 292 people (49.24\%) and the smallest number are students with an income $>$ Rp5,000,000 totaling 10 people $(1.69 \%)$. Expenditures characteristics show that most students have an expenditure of $\leq \mathrm{Rp} 1,000,000$ with a total of 327 people $(55.14 \%)$ and the number of students at least is in the expenditure range $>$ $\mathrm{Rp} 5,000,000$ is 3 people $(0.51 \%)$.

Type of Lifestyle of Indonesian Undergraduate Students

The type of lifestyle that has the largest percentage is the fulfilled lifestyle at $23.44 \%$. Believers lifestyle gained a percentage of $22.43 \%$. Furthermore, lifestyle experiencers get a percentage of $11.13 \%$ and lifestyle makers have a percentage of $10.79 \%$. 
Table 6 Type of Lifestyle of Indonesian Undergraduate Students

\begin{tabular}{lcc}
\hline Type of Lifestyle & $\mathrm{N}$ & $\%$ \\
\hline 1. Achievers & 117 & $19.73 \%$ \\
2. Strivers & 74 & $12.48 \%$ \\
3. Fulfilleds & 139 & $23.44 \%$ \\
4. Believers & 133 & $22.43 \%$ \\
5. Experiencers & 66 & $11.13 \%$ \\
6. Makers & 64 & $10.79 \%$ \\
Total & 593 & $100 \%$ \\
\hline
\end{tabular}

Source: Data processed (2020)

The Level of Financial Literacy of Indonesian Undergraduate Students

The level of student financial literacy is divided into several categories, there are $4 \%$ of all respondents included in the category of well literate, $81 \%$ of respondents included in the category of sufficient literate, and $15 \%$ of respondents included in the category of less literate and there were no respondents included in the category of not literate.

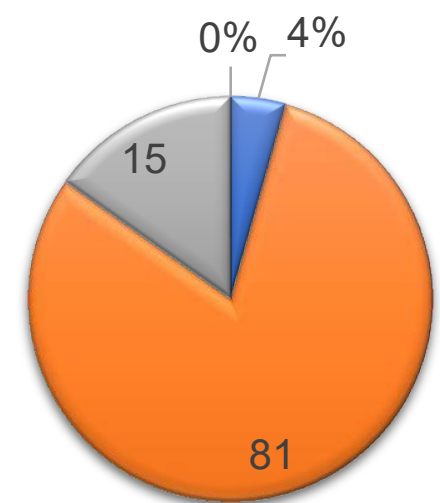

Well Literate $\square$ Sufficient Literate $\square$ Less Literate $\square$ Not Literate

Fig. 5 The level of financial literacy of Indonesian undergraduate students Source: Data processed (2020)

The average level of financial literacy of Indonesian undergraduate students is $67.45 \%$ or the average respondent can only answer 10 questions out of a total of 15 questions correctly. Based on the average, it can be concluded that the level of literacy of Indonesian S1 students belongs to the category of sufficient literate. 
Based on Figure 5, there were $4 \%$ or 26 people out of a total of 593 respondents who had a well literate level of financial literacy. Someone who well literate if they already have knowledge and beliefs about financial service institutions and financial service products including features, benefits, and risks, rights, and obligations related to financial products and services. In this category, it is concluded that there are only a few Indonesian undergraduate students who know and understand financial products and services well.

As many as $81 \%$ or 477 people out of a total of 593 respondents had a sufficient literate level of financial literacy. Someone is categorized as sufficiently literate if they have knowledge and beliefs about financial services institutions and financial products and services, including features, benefits and risks, rights and obligations related to financial products and services but do not yet have the skills in using financial products and services.

Based on the study, there were $15 \%$ or 90 people out of a total of 593 respondents who had a less literate level of financial literacy. Someone is categorized as less literate if they only know financial service institutions, financial products, and services, do not have confidence in financial products and service institutions, and do not understand the features, benefits and risks, and rights and obligations related to financial products and services.

The category of savings of respondents is visualized in Figure 6
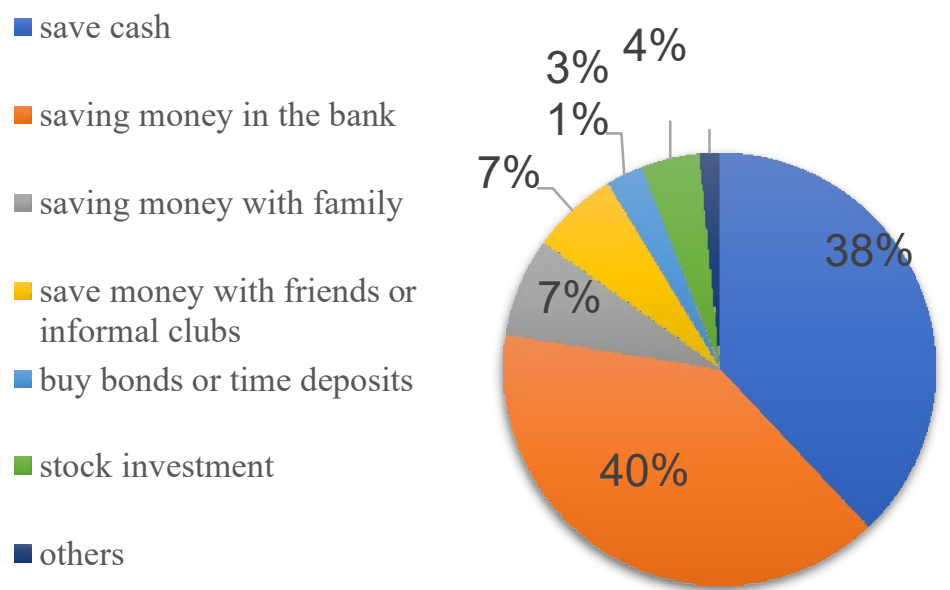

Fig. 6 Respondent's way to save their money

Source: Data processed (2020) 
Respondents can choose more than one answer to the question regarding how to save and respondents can also choose six available answer choices or have their answers and fill in the other options. Based on Figure 7 the majority of students answer how to save what they do is by saving money in the bank with a percentage of $40 \%$ or 466 people choose the answer choices. Furthermore, $38 \%$ or 448 respondents answered the choice to save cash at home or in the wallet as an option to save. There are $7 \%$ of respondents who answered saving with close family or close friends. The lowest percentage of the choice of responsibility is in the choice of buying bonds and stocks of $3 \%$ and $4 \%$. In the other answer choices, the respondent answers how to save is done by saving through a smaller risk investment, namely mutual funds, saving by buying gold, or saving by saving money in an e-wallet.

The Relationship Between Lifestyle, Financial Literacy, and Saving Behavior.

Correlation test analysis is used to explain the strength and direction of the relationship between two variables. The correlation number is in the interval -1 to 1 . If the correlation number gets closer to 1 , then the relationship between the two variables is declared perfect. The results of the correlation test between lifestyle, financial literacy, and saving behavior are presented in Table 7 .

Table 7 The result of the correlation test between lifestyle, financial literacy, and saving behavior

\begin{tabular}{ccccccccccc}
\hline & $\mathrm{X} 1$ & $\mathrm{X} 2$ & $\mathrm{X} 3$ & $\mathrm{X} 4$ & $\mathrm{X} 5$ & $\mathrm{X} 6$ & $\mathrm{X} 7$ & $\mathrm{X} 8$ & $\mathrm{X} 9$ & $\mathrm{Y}$ \\
\hline $\mathrm{X} 1$ & 1 & .208 & .542 & .276 & .370 & .269 & .210 & .377 & .027 & .412 \\
$\mathrm{X} 2$ & .208 & 1 & .234 & .077 & .079 & .286 & .090 & .097 & .055 & .235 \\
$\mathrm{X} 3$ & .542 & .234 & 1 & .366 & .336 & .304 & .207 & .428 & .032 & .461 \\
$\mathrm{X} 4$ & .276 & .077 & .366 & 1 & .203 & .193 & .086 & .293 & -.049 & .365 \\
$\mathrm{X} 5$ & .370 & .079 & .336 & .203 & 1 & .213 & .067 & .191 & .075 & .293 \\
$\mathrm{X} 6$ & .269 & .286 & .304 & .193 & .213 & 1 & .125 & .185 & .085 & .292 \\
$\mathrm{X} 7$ & .210 & .090 & .207 & .086 & .067 & .125 & 1 & .373 & .032 & .292 \\
$\mathrm{X} 8$ & .377 & .097 & .428 & .293 & .191 & .185 & .373 & 1 & .027 & .475 \\
$\mathrm{X} 9$ & .027 & .055 & .032 & -.049 & .075 & .085 & .032 & .027 & 1 & -.060 \\
$\mathrm{Y}$ & .412 & .235 & .461 & .365 & .293 & .292 & .292 & .475 & -.060 & 1 \\
\hline
\end{tabular}

Source: Data processed (2020)

Based on Table 7, the result of the correlation test shows that all types of lifestyle, namely achievers, strivers, fulfilleds, makers, experiencers, and believers, have a significant positive relationship with 
saving behavior. Lifestyle has a positive relationship with saving behavior because lifestyle is related to how a person will spend their money and how that individual can manage finances, including how to save with different levels of lifestyle between individuals.

The level of financial literacy which consists of indicators of financial planning and management as well as financial attitudes and behaviors has a significant positive relationship with saving behavior. However, financial knowledge has a significant negative relationship with saving behavior. This indicates that increasing financial planning and financial attitude will increase the saving rate, and the increasing individual knowledge about finances will decrease the saving rate. Financial knowledge will reduce the saving rate in line with research conducted by Benjamin et al. That the higher the level of individual financial knowledge, the individual tends to be more prepared to take risks and prefer to invest through portfolio purchases.

The Influence of Lifestyle and Financial Literacy on Saving Behavior

Coefficient Determination Test

A multiple linear regression test is used to see the effect of lifestyle and financial literacy on saving behavior. The analysis tool used is IBM SPPS 23. The variables used in the multiple linear regression test are lifestyle which consists of six types of gays of life, namely achievers, strivers, fulfilleds, believers, experiencers, and makers, and financial literacy which consists of planning and financial management, financial attitudes, and behavior and financial knowledge. The coefficient of determination test is used to measure the strength of the relationship between the independent variable and the dependent variable. In this study, the coefficient of determination test uses the numbers on R Square. $\mathrm{R}$ Square is a number that can explain the accuracy between the dependent variable and the independent variable. The test results for the coefficient of determination are presented in Table 8 .

Table 8 Multiple linear regression analysis

\begin{tabular}{lcc}
\hline Model & $\mathrm{R}$ & $\mathrm{R}$ Square \\
\hline 1 & 0.631 & 0.398
\end{tabular}

Source: Data processed (2020)

Based on Table 8, the result of $\mathrm{R}$ Square is 0.398 which means in percentage, namely $39.8 \%$. This indicates that the independent variable 
consisting of lifestyle and financial literacy can describe the dependent variable, namely saving behavior by $37.9 \%$. A total of $60.2 \%$ is described by other variables not examined in this study.

\section{Multiple Linear Regression Analysis}

The multiple linear regression model is a model that involves more than one independent variable. The model is used to predict the value of the dependent variable on the independent variable. The independent variable $(\mathrm{X})$ involved in this study is a lifestyle consisting of the types of achievers, strivers, fulfilleds, believers, experiencers, and makers as well as financial literacy which consists of financial planning and management, financial attitudes and behavior, and financial knowledge. The dependent variable (Y) involved in this study is saving behavior. The results of data analysis using IBM SPSS 23 software have a regression equation model of the effect of lifestyle and financial literacy on saving behavior:

$$
\begin{gathered}
\mathrm{Y}=6.278+0.144 \mathrm{X}_{1}+0.211 \mathrm{X}_{2}+0.184 \mathrm{X}_{3}+0.379 \mathrm{X}_{4}+0.241 \mathrm{X}_{5}+ \\
0.201 \mathrm{X}_{6}+0.093 \mathrm{X}_{7}+0.310 \mathrm{X}_{8}-0.361 \mathrm{X}_{9}+0.05
\end{gathered}
$$

Information:

$\mathrm{Y}=$ Saving Behavior

$\alpha \quad=$ Constanta

$\beta=$ Regression Coefficient

$\mathrm{X}_{1}=$ Achievers

$\mathrm{X}_{2} \quad=$ Strivers

$\mathrm{X}_{3} \quad=$ Fulfilleds

$\mathrm{X}_{4} \quad=$ Believers

$\mathrm{X}_{5}=$ Experiencers

$\mathrm{X}_{6} \quad=$ Makers

$\mathrm{X}_{7} \quad=$ Financial Planning

$\mathrm{X}_{8} \quad=$ Financial Attitude

$\mathrm{X}_{9} \quad=$ Financial Knowledge

$\varepsilon=$ Standard Error

Simultaneously F-Test

A simultaneous F-test is used to analyze the effect of the independent variable on the dependent variable simultaneously. The requirement for an independent variable to affect the dependent variable is to look at the significant value and the F-value. The significance value 
$(\alpha)<0.05$ and the F-value $>$ F- table shows that the independent variable simultaneously influences the dependent variable. The results of the simultaneous F-test are presented in Table 9.

Table 9 Simultaneous F-test

\begin{tabular}{lcc}
\hline Model & F & Sig. \\
\hline Regression & 42.759 & 0.000 \\
\hline
\end{tabular}

Source: Data processed (2020)

Based on the results of the simultaneous F-test, the significance value is 0.000 and less than 0.05 . This means that the results of hypothesis testing are rejected $\mathrm{H}_{0}$ and accept $\mathrm{H}_{1}$ where the independent variable has a significant effect on the dependent variable simultaneously. Thus, all of the types of lifestyle and components of financial literacy simultaneously have a significant on saving behavior based on the significant value and the F-value.

\section{Partial T-Test}

A partial T-test is used to partially analyze the effect of the independent variable on the dependent variable. The requirement for an independent variable to affect the dependent variable is to look at the significant value and the T- count value. The significance value $(\alpha)<$ 0.05 and the value of $\mathrm{T}$-value $>\mathrm{T}$ - table shows that the independent variable partially influences the dependent variable. The results of the partial T-test are presented in Table 10.

Tabel 10 Partial T-test

\begin{tabular}{lccccc}
\hline Independent Variable & $\begin{array}{c}\text { Regression } \\
\text { Coefficient }\end{array}$ & T-value & T-table & Sig. & $\alpha$ \\
\hline Achievers & 0.144 & 2.317 & 1.964 & 0.021 & 0.05 \\
Strivers & 0.211 & 3.166 & 1.964 & 0.002 & 0.05 \\
Fulfilleds & 0.184 & 3.307 & 1.964 & 0.001 & 0.05 \\
Believers & 0.379 & 4.366 & 1.964 & 0.000 & 0.05 \\
Experiencers & 0.241 & 2.949 & 1.964 & 0.003 & 0.05 \\
Makers & 0.201 & 2.510 & 1.964 & 0.012 & 0.05 \\
Financial Planning & 0.093 & 3.219 & 1.964 & 0.001 & 0.05 \\
Financial Attitude & 0.310 & 6.439 & 1.964 & 0.000 & 0.05 \\
Financial Knowledge & -0.361 & -2.813 & 1.964 & 0.005 & 0.05 \\
\hline
\end{tabular}

Source: Data processed (2020) 
Based on the results of the partial T-test, the significance value on the lifestyle variables of achievers, strivers, fulfilleds, believers, experiencers, and makers is smaller than 0.05 . Furthermore, the T-value on the lifestyle variable achievers, strivers, fulfilleds, believers, experiencers, and makers is greater than the T-table, which is 1,964. This indicates that the lifestyle of achievers, strivers, fulfilleds, believers, experiencers, and makers partially has a positive effect on saving behavior. The significance value for the financial literacy variable consisting of financial planning, financial attitudes, and financial knowledge is less than 0.05 . Furthermore, the T-value in financial planning and financial attitudes is greater than the T-table, which is 1,964. In financial knowledge, the T-count value is smaller than the Ttable value. This means that the results of hypothesis testing are rejected $\mathrm{HO}$ and accept $\mathrm{H} 1$ where the independent variable has a partially significant influence on the dependent variable, but there is a different direction in the variable of financial knowledge. All types of lifestyle, namely achievers, strivers, fulfilleds, believers, experiencers, and makers partially have a significant effect in a positive direction on saving behavior. Planning variables and financial attitudes have a significant influence in a positive direction on saving behavior. However, the variable financial knowledge has a significant effect in a negative direction on saving behavior.

The interpretation of the results of the partial T-test on how lifestyle affects saving behavior is following how the brain describes individual psychology in managing money based on research conducted by Rick et al. (2008) ${ }^{[21]}$ that the brain plays a role in decision making. Brain activity that will affect the personality of a person as a savers or spenders is the insula activity which is aroused when an individual experiences something unpleasant. Besides, according to Meir Statman (2019) ${ }^{[22]}$, someone with a tendency to spenders or savers will have a different level of satisfaction with something. This is illustrated by the levels on the pyramid.

The effect of financial literacy on saving behavior is in line with research conducted by Benjamin et al. (2013) ${ }^{[2]}$ stated that financial planning and attitudes will influence individuals in taking financial risks. Financial knowledge also influences risk-taking, such as when an individual's financial knowledge is higher, individuals will tend to choose investments with greater risk than saving. 
The Influence of The Type of Lifestyle and The Component of Financial Literacy on Saving Behavior

Based on the results of the correlation test, the type of lifestyle that has the strongest relationship is the fulfilled lifestyle. This indicates that a fulfilled lifestyle is one that tends to have a higher level of behavior to save. Fulfilleds lifestyle is one that likes information, prioritizes education, and is responsible.

The results of the correlation test between financial literacy and saving behavior indicate that financial attitudes and behaviors have a strong relationship with saving behavior compared to financial planning and knowledge. This indicates that higher financial attitudes and behaviors such as being aware of the obligation to monitor finances and realizing those bill payments will make individual finances more orderly and tend to be able to save a large proportion.

\section{Conclusion and Recommendation}

Based on the results of the research that has been done, the majority of Indonesian student's lifestyle is fulfilled with a percentage of $23.44 \%$. Furthermore, the percentage of lifestyle achievers is $19.73 \%$, the percentage of lifestyle strivers is $12.48 \%$, Indonesian students with the believers lifestyle have a percentage of $22.43 \%$, the percentage of lifestyle experiencers is $11.13 \%$, and students with lifestyle makers have a percentage of $10.79 \%$. The level of financial literacy of Indonesian students is $81 \%$ sufficient literate, $15 \%$ is in the less literate category, and the percentage of a well literate category is $4 \%$.

The relationship between lifestyle, financial literacy, and saving behavior of Indonesian students is that all types of lifestyles, namely achievers, strivers, fulfilleds, believers, experiencers, and makers have a positive relationship with saving behavior. This suggests that one unit increase in lifestyle will increase saving behavior by several points. The level of financial literacy which consists of financial planning and management, financial attitudes and behavior, and financial knowledge has a significant positive relationship with saving behavior.

The influence of lifestyle and financial literacy on the saving behavior of Indonesian students is simultaneously has a positive influence on saving behavior. Partially, lifestyle has a significant positive effect on saving behavior and financial literacy consists of financial planning and financial attitude partially has a significant positive effect on saving behavior. Financial knowledge partially has a negative effect 
on saving behavior. The contribution of the influence of lifestyle and financial literacy to saving behavior is $39.8 \%$. The type of lifestyle that influences saving behavior is fulfilleds and the component influence saving behavior is financial attitude.

Some suggestions from this study are students need to increase their skills in financial planning so they can be easier to control their income and expenses. Besides, they need to record their spending regularly to be used as information to control their future spending. The government may cooperate with universities to provide financial education to improve students as well as community knowledge.

\section{References}

[1]Bamforth J, Jebarajakirthy C, Geursen G. "Understanding Undergraduates' Money Management Behaviour: A Study Beyond Financial Literacy". International Journal of Bank Marketing. 2017.

[2]Benjamin Daniel J, Brown Sebastian A, Shapiro Jesse M. "Who is 'Behavioral'? Cognitive Ability and Anomalous Preferences". Journal of The European Economic Association. 11(6), 12311255. 2013.

[3] Delafrooz N, Paim Laily H. "Determinants of Saving Behavior and Financial Problem among Employees in Malaysia". Australian Journal of Basic and Applied Sciences. 5(7), 222-228. 2011.

[4]Forbes Magazine. “Are You Ready for Generation Z?". Available at: www.forbes.com/sites/jackmccullough/2020/02/18/are-youready-for- generation-z/amp/. 2020.

[5] Furnham A. "The Saving and Spending Habits of Young People". Journal of Economic Psychology. 677-697. 1999.

[6] Ghozali. Aplikasi Analisis Multivariate dengan Program IBM SPSS. Semarang: Badan Penerbit Universitas Diponegoro. 2016.

[7]Henager Robin, Mauldin Teresa. "Financial Literacy: The Relationship to Saving Behavior in Low-to Moderate-income Households". Family and Consumer Sciences Research Journal. 44(1), 73-87. 2015.

[8]Michman R. D, Mazze E M, Greco A J. Lifestyle Marketing: Reaching The New American Consumer. US: Greenwood Publishing Group. 2003. 
[9] Moore. "Survey of Financial Literacy in Washington State: Knowledge, Behavior, Attitudes, and Experiences". Social and Economic Sciences Research Center. 6-52. 2003.

[10] Mulyono Kemal Budi, Rusdarti. "How Psychological Factors Boost Compulsive Buying Behavior in Digital Era". International Journal of Social Economics. 47(3), 334-349. 2020.

[11] Nga Joyce K.H., L. Lisa H., Sellappan Yong Rathakrishnan D. “A Study of Financial Awareness Among Youths". Young Consumers. 11(4), 277- 290. 2010.

[12] Nguyen T, Rozsa Z, Belas J, Belasova L. "The Effects of Perceived and Actual Financial Knowledge on Regular Personal Savings : Case of Vietnam". Journal of International Studies. 10(2), 278291. 2017.

[13] Organization of Economic Co-Operation and Development/International Network on Financial Education. "Measuring Financial Literacy: Core Questionnaire in Measuring Financial Literacy: Questionnaire and Guidance Notes for conducting an Internationally Comparable Survey of Financial Literacy”. Paris: OECD. 2018.

[14] Organization of Economic Co-Operation and Development. "PISA 2012 Assessment and Analytical Framework, Financial Literacy Framework". Available at: http://www.oecd.org. 2012.

[15] Otoritas Jasa Keuangan. "Survei Nasional Literasi dan Inklusi Keuangan 2019". Available at: http://www.sikapiuangmu.ojk.go.id. 2019.

[16] Otoritas Jasa Keuangan. "Statistik Perbankan Indonesia". Available at: http://www.ojk.go.id. 2013.

[17] Ristekdikti. "Statistik Pendidikan Tinggi”. Available at: http://www.ristekdikti.go.id. 2018.

[18] Ruhaak A. Turkey: Financing Growth. Turkey: Rabo Research. 2013.

[19] Sabri M. F, Mac Donald M. "Savings Behavior and Financial Problems Among College Students: The Role of Financial Literacy in Malaysia”. Cross-Cultural Communication. 103-110. 2010.

[20] Sugiyono. Metode Penelitian Bisnis. Bandung: Alfabeta. 2013.

[21]Rick Scott I, Cryder Cynthia E, Loewenstein George. 2007.

Tightwads and Spendthrifts. Journal of Consumer Research. 34, 767-782. 
[22]Statman Meir. 2019. Behavioral Finance. CFA Institute Research Foundation. 